\title{
FAMA ESPAÑOLA DE UN SONETO DE SANNAZARO
}

El soneto en cuestión es éste:

O gelosia, d'amanti orribil freno che 'n un punto mi volgi e tien sì forte! O sorella dell'empia amara morte, che con tua vista turbi ' 1 ciel sereno!

O serpente nascosto in dolce seno di lieti fior, che mie speranze hai morte! Tra prosperi successi avversa sorte, tra soavi vivande aspro veleno!

Di qual valle infernal nel mondo uscisti, o crudel mostro, o peste de' mortali, che torni i giorni miei sì oscuri e tristi?

Tornati giù, non raddoppiar miei mali! Infelice paura, a che venisti? Or non bastava Amor con i suoi strali? ${ }^{1}$

Los primeros testimonios de la afición española a este soneto pertenecen al campo de la música. No es sino muy natural que el más antiguo de ellos se localice en Valencia, la más italianizada de las ciudades españolas en la primera mitad del siglo xvi gracias a don Fernando, duque de Calabria, que fue su virrey de 1526 a 1550 y que plantó en ella el gusto por la literatura, la música y las demás artes y costumbres de Italia. Don Fernando se señaló muy particularmente por la generosidad con que patrocinó a los músicos²; y uno de ellos, el valenciano Luis Milán, que en su Cor-

${ }^{1}$ Modernizo el texto que figura junto a la traducción de Andrés Rey de Artieda (de qua infra), y que coincide con el de las ediciones antiguas de Sannazaro.

${ }^{2}$ Sobre este mecenazgo puede ver el lector curioso mis "Notas musicales en torno a Oviedo y a la casa real de Nápoles", en apéndice a la traducción 
tesano describió las fiestas de la corte, musicalizó nuestro soneto en su Libro de música de vihuela de mano intitulado "El Maestro"' (Valencia, 1536). Diez años después hizo otro tanto Alonso Mudarra en sus Tres libros de música en cifra para vihuela, publicados en la ya muy cosmopolita Sevilla de $1546^{3}$.

La más antigua de las versiones españolas puede ser ésta:

¡O çelos, de amor terrible freno qu'en un punto me buelve y tiene fuerte! Hermanos de crueldad, deshonrrada muerte que con tu vista tornas el çielo sereno.

¡O serpiente naçida en dulçe seno de hermosas flores, que mi esperança es muerta! Tras prósperos comienços, adversa suerte; tras suave manjar, rezio veneno.

¿De quál furia infernal acá saliste, ó cruel monstruo, ó peste de mortales, que tan tristes y crudos mis días hezistes?

¡Tórnate al infierno sin mentar mis males!

Desdichado miedo, ¿a qué veniste?, que bien bastava Amor con sus pesares ${ }^{4}$.

Este desdichadísimo soneto, en el único manuscrito que nos lo ha transmitido - el llamado "Cancionero de Gayangos", actual ms. 17.969 de la B.N.M.- , se atribuye nada menos que a Garcilaso de la Vega, lo mismo que un segundo soneto, "El mal en mí ha hecho su çimiento... ", aún más defectuoso que el otro, y dos composicioncitas castellanas (cf. la ed. cit. de Rivers, p. xxii).

del libro de A. Gerbi, La naturaleza de las Indias nuevas, de Cristóbal Colón a Gonzalo Fernández de Oviedo, México, 1978, pp. 492-497.

${ }^{3}$ Ed. de Emilio Pujol, Instituto Español de Musicología, Barcelona, 1949, pp. 116-118. Composición hecha para voz con acompañamiento de vihuela; pero es seguramente adaptación de un madrigal polifónico (es fácil restituirle su forma original a cuatro voces). No conozco, desgraciadamente, la musicalización de Luis Milán. El texto empleado por Mudarra ofrece no pocas variantes: 2 mi tiri e tien si forte; 3 empia e cruda morte; 6 che con tue voglie mie speranze morte [sic]; 7 tra felice [sic] succesi; 9 di qual boca infernal; 11 per far gli giorni miei; 12 Tornati giù, non aumentar miei mali; 13 ad quid venisti? Casi todas estas alteraciones deben proceder de una mano italiana. Lo cual puede hacer pensar que el madrigal polifónico original, con esa letra, es obra de un músico italiano.

${ }^{4}$ Garcilaso de la VeGa, Obras completas, ed. Elias L. Rivers, Castalia, Madrid, 1964, p. 179. Corrijo la puntuación del v. 1 (Rivers: "O çelos de amor, terrible freno...!"') y restituyo las lecciones del manuscrito en los vv. 6 y 11 . 
Desde su primera publicación, en 1880, todos los críticos han aceptado la autenticidad de las coplas castellanas, pero no la de los sonetos, a causa, naturalmente, de sus monstruosos defectos. El segundo soneto tiene una tónica conceptual y expresiva ciertamente garcilasiana ${ }^{5}$. El otro, en cambio, constituiría un caso excepcional, pues Garcilaso, a diferencia de Boscán - y de sus inmediatos sucesores, Cetina, Acuña y los demás-, nunca tradujo verdaderamente un soneto italiano. Se podría decir que bastantes muestras dio de su admiración por el Zannazaro de la Arcadia. Lo difícil de aceptar - aun corrigiendo los errores mecánicos del copista $^{6}$ : el tornas del v. 4, por ejemplo, tiene que ser error de copia por turbas (turuas), y el mentar del v. 12 tiene que ser aumentares que Garcilaso, por muy novicio que lo imaginemos, haya podido escribir, ni aun en borrador, versos tan mal rimados y tan desmañadamente escandidos. Imposible que su aprendizaje haya sido tan penoso.

La primera traducción impresa es la que figura, anónima, en el Cancionero general de obras nueuas impreso por Esteban Gabriel de Nájera en Zaragoza, 1554:

${ }^{5}$ Cf. los versos finales: ". . .el mayor bien que tengo es siempre llorar: / ipensad quál será el mal do el bien es el que digo!", tan patéticos y tan torpemente escandidos. En su editio minor (Clásicos Castalia, 1969), pp. 75-76, Rivers imprime ambos sonetos con un texto "libremente enmendado" (y sin notas críticas). El segundo se deja leer bastante bien, pero no así el primero. Baste un ejemplo: “. . honrada muerte / que, vista, tornas el cielo sereno" es un contrasentido.

${ }^{6}$ El Cancionero de Gayangos contiene buen número de composiciones de Garcilaso (además de las cuatro piezas mencionadas): nueve sonetos, dos églogas, una canción y tres coplas castellanas. En todas ellas llama la atención la torpeza del copista. He aquí algunos de sus disparates: "adonde sé qu' [h]e de morir tan apretado" (Soneto II, 2: 13 sílabas); "y quanto yo de vos escrivir desseo" (Son. V, 2: 12 sílabas); "arrimada a tus olores" (Égloga I, 40, en vez de loores); "más quell alma ardientes" (Égl. I, 360, en vez de más que la llama); "solamente en un día"' (Égl. III, 10, en vez de en vida); "Daphne, con el cuchillo suelto al viento" (Égl. III, 153, en vez de con el cabello). De todos modos, el interés de este manuscrito es innegable: ofrece el único texto de dos coplas castellanas cuya autenticidad no puede sino admitirse, y algunas de sus variantes ofrecen lecciones mejores que las de la edición barcelonesa, por ejemplo "dándome a entender yo que mi flaqueza"' (Canción I, 49; en la ed. barcelonesa falta yo, y el verso cojea); "las verdes ovas" (Égl. III, 109) les están mejor a las ninfas del Tajo que "las verdes hojas"; el texto del Son. XIV, primer terceto, "Assí a mi mi enfermo pensamiento / que en su daño es me pide, yo querría / quitalle este mortal mantenimiento", ostenta dos gruesos disparates, pero tras ellos se esconde un texto más satisfactorio que el impreso en Barcelona. 
Celos, de amor terrible y duro freno, que me bolvéys, paráys y tenéys fuerte; parientes muy cercanos de la muerte, qu'el cielo escurecéys claro y sereno.

¡Ó serpiente escondida en dulce seno de flores, qu'eres causa se convierte el próspero sucesso en dura suerte, y el suave manjar hazes veneno!

¿De quál furia infernal acá as salido, monstruo cruel que a todos has lisiado y a mí en tan gran angustia me has metido?

¡Buelve, no sigas más lo començado! Desdichado temor, ¿a qué has venido? ¿No me bastava Amor con su cuydado??

Ésta sí es una traducción seria, irreprochable en cuanto a las rimas y en cuanto a la medida. El traductor, que bien podría ser . Juan Coloma ${ }^{8}$, calca las dos rimas de los cuartetos sannazarianos, como hizo también el pseudo-Garcilaso (y como harán casi todos los demás traductores), pero sustituye las de los tercetos por otras (como harán asimismo casi todos los otros traductores). Desgraciadamente, no le saca ningún provecho a esa mayor libertad: los tercetos, fluidos y enérgicos en Sannazaro, son aquí muy desvaídos, muy pedestres; el traductor ni siquiera se dio maña para trasladar la imagen de las flechas ("Or non bastava Amor con i suoi strali?'), sino que salió del paso con un incoloro cuidado. Los cuartetos, más ceñidos al modelo, son por ello menos flojos, pero muestran la poca habilidad que tuvo el traductor para resolver un par de problemas. El soneto de Sannazaro está dirigido a una aterradora figura femenina, gelosia, hermana de la morte (sería bueno poner estos nombres con mayúscula). El traductor hubiera podido decir celosía, o gelosía - como llegó a decir Gutierre de Cetina-; pero tal vez celosía tenía ya el significado predominante de 'cierto enrejado de ventanas'. Así, pues, no tuvo más remedio

7 Texto reproducido por Alfred Morel-Fatio, L'Espagne au XVt et au XVIT siècle, Heilbronn, 1878, p. 584. Termina así: " . . venido / do me bastava amor con su cuydado". Yo corrijo. Lamento no conocer el artículo de J. P. WICKERSHAM CRAWFORD, "Notes on the Spanish Cancionero general of 1554", RR, 7 (1916), 328-337.

${ }^{8}$ Sus composiciones son las que más abundan en el mencionado Cancio. nero de 1554. Entre los poetas de la "primera generación", Coloma es quizá el más pedísecuo imitador de Garcilaso. Cf. A. Alatorre, "Sobre la «gran fortuna" de un soneto de Garcilaso", NRFH, 24 (1975), p. 153, nota 18. 
que traducir celos, con ese plural que convierte al personaje único Gelosia en una multitud de monstruitos ${ }^{9}$. Su solución, en todo caso, es pobre: "parientes muy cercanos de la muerte" (¿por qué no, por ejemplo, "hermanos de la dura amarga muerte"?). El otro problema es el morte del v. 6 , participio de morire, distinto del sustantivo morte del v. 3. Imposible repetir muerte. También aquí la solución es pedestre (y sintácticamente violenta): "que eres causa se convierte...", etc. Además, en el v. 2 dice Sannazaro que la gelosia es para el amante lo que el freno para un caballo a todo galope: lo encabrita y a la vez lo inmoviliza ("in un punto mi volgi e tien sì forte"). Los tres verbos de la traducción, "me bolvéys, paráys y tenéys", desdibujan la imagen.

Esta traducción tuvo, sin embargo, alguna fama, como lo demuestra su inclusión en las Flores de baria poesia, con variantes poco significativas, pero que indican que el texto no procede del Cancionero impreso en 1554, sino de otro manuscrito, o bien -hipótesis no descabellada - de la cabeza de alguien que sabía de memoria esa traducción del famoso soneto ${ }^{10}$.

He aquí ahora la traducción de Hernando de Acuña:

¡Ó celos, mal de cien mil males lleno, interior daño, poderoso y fuerte, peor mil vezes que rabiosa muerte, pues bastas a turbar lo más sereno!

Ponçoñosa serpiente, que en el seno te crías donde vienes a hazerte; en próspero sucesso adversa suerte y en sabroso manjar cruel veneno.

${ }^{9}$ Celos, en plural, es como dicen casi todos los textos mencionados en este artículo; el singular celo (cf. infra, nota 26) debe haber sido raro en este sentido. En cuanto a celosía, el DCECH ofrece datos algo confusos: "celosía 'celos' (ss. XV-XVII), 'enrejado de madera' "'; pero la documentación aducida se refiere toda, evidentemente, al 'enrejado', no a los 'celos'. El único que no se arredra ante el italianismo gelosía es Gutierre de Cetina, soneto "Cruel y venturosa jelosia..." (Gallardo, 'Ensayo, t. 2, col. 418; ed. Hazañas, t. 1, p. 53), que no tiene que ver con el de Sannazaro. Este soneto de Cetina figura también en las Flores de baria poesía, el célebre cancionero compilado en México en 1577 (ed. Margarita Peña, UNAM, México, 1980, p. 359): “Cruel y uenturosa geluzia..."

10 Flores de baria poesía, pp. 308-309. La editora, por cierto, se la atribuye denodadamente a Garcilaso. Sería, según eso, el resultado de la elaboración del informe borrador que antes hemos visto (una elaboración tan a fondo, que la editora se ve obligada a poner al pie de la página, como "variantes", prácticamente todas las palabras de la versión pseudo-garcilasiana). 
¿De quál valle infernal fuiste salido?

¿Quál Furia te formó? Porque Natura

nada formó que no sirviesse al hombre.

¿En qué constelación fuiste nacido?

Porque no sólo mata tu figura,

pero basta a más mal solo tu nombre ${ }^{11}$.

Acuña da a sus cuartetos las rimas ya consagradas, pero renuncia, sorprendentemente, a tres de las imágenes del original: freno, sorella y lieti fior. En su lugar introduce, por una parte, una carga enfática (mal lleno de cien mil males, peor mil veces que la muerte), y por otra parte una visión de los celos no como monstruo que viene de fuera, sino como daño interior. La imagen de la serpiente se traslada a un nivel psicológico: la serpiente no se esconde en las flores, sino que nace en el seno mismo del amante. Hay que reconocer, sin embargo, que el v. 6 es endeble (aunque no tanto como el de la traducción anterior): la frase "en el seno / te crías donde vienes a hazerte" es pleonástica, o sea vacía; equivale a 'te crías en el seno donde te crías'. Los tercetos introducen también elementos nuevos: el elogio típicamente renacentista de la Naturaleza (cf. Garcilaso, Égl. II, 80-81: “ ¡Oh Natura, cuán pocas obras cojas / en el mundo son hechas por tu mano!") y la ponderación final, en la que se elimina una vez más la imagen de los strali. Evidentemente, lo que a Acuña le importaba más que nada era la fluidez, la soltura.

Jerónimo de Lomas Cantoral, coetáneo y paisano de Acuña (ambos eran vallisoletanos), se toma menos libertades en su traducción:

¡Ó zelos, de amadores duro freno que en vn punto me buelue y tiene fuerte! ¡Ó fiero hermano de la negra muerte que con tu vista turbas lo sereno!

¡Ó serpiente ascondida en dulce seno de alegres flores, y quán presto vierte el bien tu ira, de la mejor suerte, manjar amargo de ponçoña lleno!

¿De quál valle infernal veniste al mundo, ó rabia y mortal peste, por quien ardo y en medio del mayor fuego me hielo?

11 AcuÑa, Varias poesías, ed. Antonio Vilanova, Selecciones Bibliófilas, Barcelona, 1954, p. 252. 
Torna, monstruo cruel, torna al profundo, que para consumir mi vida en duelo basta de Amor el riguroso dardo ${ }^{12}$.

Las rimas de los cuartetos son las consabidas, pero es curiosa la sustitución de veneno por "de ponçoña lleno" en el v. 8, - sustitución ligada a un cambio conceptual: en vez de ser las gotas que envenenan el manjar del amor, los celos son el manjar. Como en las traducciones anteriores, también en ésta son visibles las huellas del esfuerzo por resolver el problema de la rima morte en el v. 6: la frase "quán presto vierte / el bien tu ira, de la mejor suerte" es bastante violenta (deshaciendo el hipérbaton, lo que se entiende es que la ira de los celos vierte o derrama con gran rapidez "el bien de la mejor suerte", o sea que extingue la alegría del amante más venturoso, como quien vuelca violentamente una copa de vino; pero es extraño atribuir a una serpiente ese verter). Al igual que Acuña, Lomas introduce en el primer terceto un elemento que no está en Sannazaro, pero la antítesis petrarquista arder/helarse le permite trasladar, por fin, la imagen de los strali (rimas ardo : dardo). Por lo demás, en esta traducción están presentes las demás imágenes - freno, sorella, lieti-fior- que Acuña omite. Salvo lo dicho de los vv. 6-7, es el suyo un soneto tan fluido, de tan grata lectura, como el de Acuña; y al mismo tiempo es más fiel al texto italiano. Si como poeta original parece Lomas de tercera fila, como traductor es de primera. Bien visto, ésa fue su especialidad ${ }^{13}$.

12 Jerónimo de Lomas Cantoral, Obras, Madrid, 1578, fol. 114r. Algunos extractos de este libro pueden verse en Gallardo, Ensayo, t. 3, cois. 401416. En uno de sus poemas elogia Lomas Cantoral a ocho poetas de Valladolid, uno de ellos Acuña: "Cante, Acuña, de ti el divino Apolo..." (Las Obras de Acuña, que debe haber sido algo mayor que Lomas, se publicaron póstumamente en 1591).

${ }^{13}$ Véase JosEPH G. Fucilla, Estudios sobre el petrarquismo en España, anejo 72 de la RFE, Madrid, 1960, pp. 119-133; N. Alonso CoRTÉs, "Jerónimo de Lomas Cantoral", $R F E, 6$ (1919), 375-388; E. Segura Covarsí, "Don Jerónimo de Lomas Cantoral, un petrarquista olvidado", RLit, 21 (1952), 3975. Dice Gallardo, loc. cit., col. 404: "En [sus] versos a la italiana hallo no sé qué de premioso que obsta a la franca expresión de los afectos, aunque tiene rasgos hermosos. Como quiera, pocas piezas suyas tienen tal novedad en el pensamiento, o en la dicción, que puedan servir de modelo u ocupar plaza distinguida en una colección de poesías castellanas"; pero al dar cuenta de las tres Piscatorias traducidas de Luigi Tansillo (y no mencionadas por Fucilla) comenta que "se dejan leer con sabor y gusto". La misma apreciación merecen sonetos como "Abrióme Amor con diestra mano el lado / yzquierdo..." 
Lomas tradujo asimismo el soneto de Luigi Tansillo, "O d'invidia e d'amor figlia sì ria..."', que es imitación del de Sannazaro. Lo hecho por Tansillo se transparenta perfectamente en la traducción de Lomas:

¡Ó de embidia y de amor hijo malino, que de tu padre robas el sossiego! ¡Argos al mal, y al bien qual topo ciego, zelos, ministro de dolor contino!...

¡Ó rauia de ti mesma desamada...!

Si se pudiesse a ti cerrar la entrada, tanto el reyno de Amor sería más bello quanto el mundo sin odio, muerte o $\mathrm{yra}^{14}$.

\footnotetext{
[(traducido de Petrarca, "Amor con la man destra il lato manco / m'aperse....") Ärtieda ("Artemidoro"), coetáneo y amigo de Cervantes:

¡Celos, que a los que amáys servís de freno, y dándome mil bueltas me assís fuerte! ¡Ó furia y sombra, hermana de la muerte, que anublas con tu vista el sol sereno!

Sierpe escondida en un jardín ameno, do muere mi esperança en solo verte; en la prosperidad contraria suerte $y$ en el dulce manjar me das veneno.

Dime, ¿̇de qué infernal prisión saliste, que los mortales pechos inquietas y esta vida me das amarga y triste?

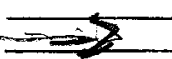

y "Cabellos de oro sobre nieve pura..." (traducido de Bembo, "Crin d'oro crespo, e d'ambra tersa e pura...").

${ }^{14}$ Lomas Cantoral, Obras, fol. 115r; y cf. Fucilla, Estudios, p. 132. Otro italiano que imitó a Sannazaro fue Bernardo Tasso: "Pallida gelosia ch'a poco a poco..." , soneto traducido por un poeta aún más olvidado que Lomas: Jerónimo de Heredia, Guirnalda de Venus, Barcelona, 1603 (Fucilla, pp. 278279). El núm. 133 de los “237 sonnets" publicados por R. Foulché-DelbosC en $R H i, 18$ (1908), 488-618, está obviamente inspirado en el de Sannazaro: “ $\mathrm{O}$ enemiga de amor, desconfianza, / furia infernal de ingratitud nacida, / que con tu amarga hiel mi dulce vida / entristeces con súbita mudanza!. . " Su autor es "Lizama", otro poeta de la generación anterior a la de Lope y Góngora (uno de los sonetos de Lizama está dirigido a Pedro Laínez). Los tercetos de ese soneto dicen: "Si piensas con tu triste compañía, / aspereza, desdén, yra, despecho, / afloxar solo un punto la cadena, // engáñaste, que amor dentro en mi pecho / jamás ha de morir hasta aquel día / que el último será de vida y pena".
} 


\author{
¡Buélvete allá, que el coraçón me aprietas! \\ Infelice temor, ¿a qué viniste? \\ $\mathrm{Di}$, ¿no bastava Amor con sus saetas? ${ }^{15}$
}

Obsérvese, en primer lugar, que Artieda no sólo mantiene las rimas de los cuartetos, sino también, a diferencia de sus tres predecesores, una de las de los tercetos; $y$, en segundo lugar, que nadie había resuelto tan gallardamente como él el problema del v. 6 (mie speranze hai morte): al renunciar a la rima seno del v. 5 y al convertir el "dolce seno / di lieti fior" en jardín ameno, Artieda se reserva todo el v. 6 para decir fluidamente, sin violencias, lo mismo que allí dice Sannazaro (y los lieti fior no quedan sacrificados del todo). Las demás imágenes del soneto italiano se trasladan con absoluta naturalidad, incluyendo los strali del verso final (y las saetas están aquí mejor colocadas que el dardo en la traducción anterior). Rey de Artieda, más atractivo que Lomas como poeta original ${ }^{16}$, es, como traductor, tan de primera fila como él, con la diferencia

${ }^{15}$ Discursos, epistolas y epigramas de Artemidoro [Zaragoza, 1605], ed. Antonio Vilanova, Selecciones Bibliófilas, Barcelona, 1955, p. 209. El editor recoge en el prólogo las noticias que se tienen sobre Rey de Artieda (1549-1613), y reproduce los elogios que le hicieron Cervantes y Lope. Para facilitar la comparación con las otras versiones he suprimido los signos de interrogación que aparecen en los vv. 7-8, así del texto italiano como de la traducción. (El sentido no cambia).

${ }^{16}$ Es notable el juicio que le merece Artieda al P. Francisco Javier AleGRE, en nota a su traducción del Arte poética de Boileau (Opúsculos inéditos..., ed. Joaquín García Icazbalceta, México, 1889, p. 61). Comentando el pasaje famoso en que Boileau, después de tender la mirada sobre el panorama sonetil europeo, reflexiona que de tantísimos sonetos "dos o tres entre mil / apenas pueden leerse, y me propaso", amplía Alegre la lista de los sonetistas, repite que "de tantos millares de sonetos no sé si podrá sacarse una docena sin defecto", y añade: "Sólo pondré aquí uno que no hallarás fácilmente en otra parte, y que por la simplicidad del pensamiento, por la viveza de la imagen, por la naturalidad, hermosura y gracia del estilo lo tengo por la pieza mejor que se ha escrito en este género, y capaz él solo de inmortalizar el nombre de Andrés Rey de Artieda"; y a continuación copia entero el soneto "A los discursos vanos" " Como a su parecer la bruja vuela...", ed. Vilanova, p. 212), delicioso en efecto por su humor cuasi-cervantino. Lo raro es que Alegre diga que el lector no hallará fácilmente ese soneto en otra parte. Habría que pensar que su traducción de Boileau es anterior a 1768, año en que apareció el primer tomo del Parnaso de Sedano, en cuya p. 360 se incluye ese soneto de Artieda. Pero es evidente que la traducción de Boileau se hizo cuando ya habían transcurrido algunos años del destierro italiano de Alegre (1767-1788), pues los conocimientos de literatura europea de que da muestras no pudo adquirirlos sino en Italia. (El soneto "A los discursos vanos" es una de las poquísimas muestras de la poesía de Artieda que figuran en el desdichado t. 62 de la $B A E$, p. 540). 
de que no hizo sino cinco traducciones. Era poeta estricto, y salta a la vista la cuidadosa seriedad con que hizo su labor: cada uno de estos cinco sonetos va precedido de su original italiano ${ }^{17}$, evidentemente para invitar al lector a hacer lo que aquí estoy haciendo (o tratando de hacer).

Éste parece ser el lugar que cronológicamente le corresponde a una sexta traducción, contenida en la Poética silva de la biblioteca de Campomanes, acerca de la cual confieso no saber sino lo que de ella dice Gallardo. En el fol. 145 de ese manuscrito hay un soneto (evidentemente anónimo) que comienza " $\mathrm{O}$ celo, del amante horrible freno...!'"18

En 1605, el mismo año en que aparecieron las poesías de Rey de Artieda, se publicaba en Valladolid la Primera parte de las Flores de poetas ilustres de España, recogidas por Pedro Espinosa, donde figuran dos traducciones de nuestro soneto: la de Góngora y la de Jerónimo de Mora. Comencemos con esta segunda:

¡Celos, de quien bien ama amargo freno, que a un tiempo me corréis y paráis fuerte! iSombras de la enojosa y triste muerte, tiniebla que se opone al sol sereno!

¡Víboras encubiertas en el seno de dulces flores, mal que no se advierte! ¡Tras prósperos principios triste suerte, y en sabroso manjar mortal veneno!

¿De cuál gruta infernal acá salistes, ruina universal de los mortales? ¡Ay! ¿por qué perseguís mis ojos tristes?

17 Además del soneto de Sannazaro, Artieda tradujo uno muy famoso de Petrarca, "Cesare poi che '1 traditor d'Egitto...", uno de Serafino Aquilano, "Io pur travaglio e so che '1 tempo gioco...", y dos que él atribuye a Luigi Alamanni: "Dopo di haver fuor di Pannonia spinto..." y "Superbi colli, e voi sacre ruine... ', el segundo, muy celebrado, es en realidad de Castiglione; Fucilla, Estudios, p. 210, dice no haber hallado el primero en las obras de Alamanni.

${ }^{18}$ Gallardo, Ensayo, t. 1, col. 1061. La Poética silva debe ser contemporánea de las Flores de Espinosa (a las que en seguida me referiré); pero el tenor de sus composiciones (a juzgar por las abundantes muestras que edita Gallardo) nos sitúa más en los últimos decenios del siglo XVI que en los comienzos del XVII. Se echa de menos la "modernidad" de Góngora y de Luis Martín de la Plaza (aunque está representado Lope con algunos de sus sonetos más famosos). Los ingenios de la Poética silva son casi todos granadinos. Varias de las composiciones que figuran en ella están también en las Flores de Espinosa. 
Volvé al infierno ya, dejad mis males.

Maldito sea el punto en que nacistes, que bien bastaba Amor sin furias tales ${ }^{19}$.

Es una traducción tan buena como la de Artieda, y sin embargo difiere de ella en no pocos detalles. Mora mantiene el plural de celos hasta el final: "Celos. . ., volvé al infierno"' (todos los traductores han terminado en singular), pero quizá sintió que era violento pluralizar el sorella del v. 3 diciendo por ejemplo "hermanos de la odiosa y triste muerte". Su v. 3 parece así menos fiel que el de Artieda, "¡oh furia y sombra, hermana de la muerte!', pero en realidad equivale a lo mismo: de dos hermanos inseparables se dice que son como el cuerpo y su sombra. En el v. 12, el "dejad mis males" parece menos enérgico que el "non raddoppiar miei mali" de Sannazaro, pero también dice lo mismo: bastante dolor es el estar enamorado. El v. 14 es tan enfático como el del original, pese a la omisión de las 'flechas'. Los strali de Sannazaro se refieren a la tortura del amor; las furias de Mora, a la tortura de los celos. Además, este v. 14 está como preparado por el "dejad mis males"'. De manera parecida salva Mora el escollo del v. 6 (el segundo morte): "mal que no se advierte" se traba muy satisfactoriamente con la imagen de la serpiente oculta en las flores ${ }^{20}$. Por otra parte, hay que observar que él mantiene todas las rimas del soneto original. Ya lo había hecho el pseudoGarcilaso, pero ¡qué contraste entre la fluidez del soneto de Mora y las chapucerías del otro!

La traducción de Góngora es ésta:

${ }^{19}$ Primera parte de las Flores..., ed. Francisco Rodríguez Marín, Sevilla, 1896, p. 185. Hay que observar que Espinosa ignoraba el nombre de pila del traductor, pues el soneto se atribuye a "N. de Mora" en la edición de 1605. Quien lo averiguó fue Gallardo (anotación manuscrita en su ejemplar de las Flores, copiada por Rodríguez Marín, p. 401: "Jerónimo. Cervantes elogia a este ingenio aragonés en su Calíope"). Es éste el único texto de Mora recogido en las Flores. También de Artieda hay un texto único, el soneto "Vive casi en la bienaventuranza..." (pp. 65-66), que en las obras de Artieda (ed. Vilanova, p. 200) se intitula "Contra la esperança" y se presenta con algunos retoques.

${ }^{20}$ No evita, en cambio, el pequeño escollo del v. 2. Por muchos ejemplos que se aduzcan de adjetivos empleados con función adverbial, seguramente sonaba un poco violenta, italianizante quizá, la expresión "me corréis y paráis faerte" (y cf. en las otras versiones "me assís fuerte", "me bolvéys, paráys y tenéys fuerte", "me buelue y tiene fuerte"). Por algo el v. 2 de Acuña suena tan natural: "interior daño, poderoso y fuerte". 
¡Oh niebla del estado más sereno, furia infernal, serpiente mal nacida! ¡Oh ponzoñosa víbora escondida de verde prado en oloroso seno!

¡Oh entre el néctar de amor mortal veneno, que en vaso de cristal quitas la vida! ¡Oh espada sobre mí de un pelo asida, de la amorosa espuela duro freno!

¡Oh celo, del favor verdugo eterno! Vuélvete al lugar triste donde estabas', o al reino (si allá cabes) del espanto; mas no cabrás allá; que pues ha tanto que comes de ti mesmo y no te acabas, mayor debes de ser que el mismo infierno ${ }^{21}$.

Es éste uno de los trece admirables sonetos que Góngora compuso en 1582 , a los veintiún años, y que se imprimieron por primera vez en 1605 en las Flores de Espinosa. A esa edad era Góngora un maestro"2. El soneto "A los celos" es digno compañero

${ }^{21} \mathrm{El}$ texto de las Flores, p. 220 (y cfi nota de Rodríguez Marín, p. 416), tiene intercambiados los vv. 9-10: "Vuélvete al lugar triste donde estabas, / joh celo...!", etc. El texto que doy es el del manuscrito Chacón, o sea el de las eds. de Foulché-Delbosc y Millé Giménez (coinciden también las otras fuentes antiguas: Vicuña, Hoces, Faría y Sousa). La forma CDE ECD que tienen los tercetos en las Flores es sumamente rara; la forma CDE EDC del texto definitivo (rimas "en espejo"), mucho menos rara, aparece en otros dos sonetos de Góngora (ed. Millé, núms. 298 y. LXXIII). Pero el cambio debe haberse debido más bien a razones de simetría: el ;Oh. . . encabeza así los tercetos, formando serie regular con los cuatro $; O h . .$. ! de los cuartetos. Hay otra pequeña variante: en los vv. 13-14, las Flores dicen mesmo/mesmo, no mesmo/mismo (en Vicuña, según Rodríguez Marín, se lee mismo/mismo).

${ }^{22}$ Lo era ya a los diecinueve ("Hermana Marica" es de 1580). Góngora debió haber quemado gran cantidad de sonetos primerizos. Vale la pena observar que los 13 fechados en 1582 y los 7 fechados en 1583 se imprimieron todos en las Flores de Espinosa. En cambio, de los 32 fechados en los diecisiete años que van de 1584 a 1600, sólo 13 figuran allí. Las Flores estaban listas para la imprenta a fines de 1603. En su gracioso prólogo "Al lector" pondera Espinosa el "trabajo tan grande" que le costó armar su antología: jeso de "escalar el mundo con cartas" para invitar a los poetas y, "después de pagar el porte", encontrarse con que lo que le mandan es inservible! Él esperaba recibir únicamente cosas muy modernas y muy buenas, y a menudo no le llegaban sino antiguallas, "o quando más algún soneto cargado de espaldas y corto de vista". Así, pues, "para sacar esta Flor de harina he cernido dozientos caýzes de poesía, que es la que ordinariamente corre". Pero sin duda los 33 sonetos y 4 canciones de Góngora que hay en las Flores le llegaron a Espinosa como harina ya cernida. (Góngora es el poeta más abundantemente representado en ellas). 
de una obra maestra como "Mientras por competir con tu cabello...", traducción del "Mentre che l'aureo crin v'ondeggia intorno. .." de Bernardo Tasso, hecha en el mismo año 1582. Claro que en uno y otro caso se muestra Góngora no sólo como maestro, sino también como discípulo, - un discípulo deslumhrado por los maestros italianos y a la vez muy decidido a superarlos ${ }^{23}$. El "método" seguido en la traducción de "O gelosia... .!" ejemplifica muy bien la manera como Góngora entendió esa empresa. A diferencia de Jerónimo de Mora, que se obligó a reproducir todas las rimas del original, Góngora no tomó de él sino freno, sereno, seno y veneno, y ni siquiera puso las palabras en ese orden: el "orribil freno" del v. 1 está ahora en el 8, y el apóstrofe inicial, "O gelosia...!", ha pasado al primer terceto. Salvo el pseudoGarcilaso, todos los traductores, quién más, quién menos, han tenido que hacer acomodos (pequeñas omisiones, adiciones, traiciones) para que el soneto suene. Góngora los deja muy atrás a todos. Véase el final de los cuartetos: la imagen de la espada no está en Sannazaro, y tampoco la de la espuela, tan certeramente contrapuesta a la de freno ( $\mathrm{y}$ tan fuertemente erótica). Y véanse, sobre todo, los tercetos, que traducen el pensamiento de Sannazaro, sí, pero diciendo mucho más que él: la ponderación de la "monstruosidad" de los celos no es en Sannazaro tan unitaria y tan enérgica como en Góngora: "Vuélvete [al infierno] si allá cabes..., -mas no cabrás allá" ${ }^{24}$, etc. Acuña se atrevió a suprimir la imagen del freno y a añadir una reflexión sobre las obras de la Naturaleza. Los atrevimientos de Góngora son mucho mayores: no se limitan a resolver problemas menudos y dispersos de medida o de rima, sino que atañen al soneto en su conjunto, en su estructura. Hay que comparar los tercetos, y en particular el verso último, del original y de la traducción, para ver mejor hasta dónde llega el cambio de estructura. El verso final de Sannaza-

${ }^{23}$ Además de los mencionados sonetos de Sannazaro y B. Tasso, Góngora tradujo en 1582 otros cuatro (uno del mismo B. Tasso, otro de Minturno y dos de Torquato Tasso); en 1583 tradujo sólo tres, en 1584 otros tres (entre ellos el espléndido "La dulce boca que a gustar convida...", de T. Tasso) y en 1585 uno solo ("Aunque a rocas de fe ligada vea...", del mismo); ésta fue su última traducción. Salvo "La dulce boca... " y "Aunque a rocas... ", todas las traducciones de Góngora figuran en las Flores.

${ }^{24}$ La anticipación sintáctica "al reino (si allá cabes) del espanto" es muy de Góngora. Cf.: “ “. . grítale el pueblo, haciendo de la plaza / (si allá se alegran) un alegre infierno" (ed. Millé, núm. 251, soneto de 1588); y también: “ “. .juraré que lució más su guirnalda, / con ser de flores, la otra ser de estrellas, / que la que ilustra el cielo en luces nueve" (núm. 219, de 1582). 
ro, "Or non bastava Amor con i suoi strali?"' será muy patético, muy hermoso, pero es ilógico, como también es ilógico el "non raddoppiar miei mali!' que le precede. Arrastrado por su retórica petrarquista, Sannazaro ha olvidado que el amor, en los cuartetos, no es un mal, una tortura (redoblada por los celos), sino el bien por excelencia: cielo sereno, flores alegres, sucesos felices, sabrosos manjares (arruinado todo por los celos). El verso inicial de los tercetos de Góngora no sólo recoge el "O gelosia . . ."' de Sannazaro, sino que compendia en una sola las diversas imágenes de los tercetos: los celos son el verdugo del favor (del amor que hasta ese momento ha estado vivo, "en acción"), y el verso final es no sólo tan hermoso y patético como el de Sannazaro, sino también mucho más coherente ${ }^{25}$. Por otro lado, es de notar el cuidado con que Góngora evita trasladar a su soneto los plurales speranze, successi, vivande: todas sus imágenes, así las que se refieren al amor como las que se refieren a los celos, comenzando con el nombre mismo de los celos $^{26}$, están en singular: cielo despejado y niebla, prado florido y víbora, néctar y veneno, espuela y freno, etcétera.

Ninguna explicación de lo que fue el Barroco puede olvidar la exacerbada preocupación estructural, el "horror del vacío", la lucha por la máxima congruencia entre el conjunto y los detalles, entre el significado total y los significados parciales. Las diferencias entre la traducción de "O gelosia. . .!" por el anónimo de 1554 y la traducción de Góngora miden muy bien la distancia que hay entre la masa de la poesía "quinientista" y la nueva poesía que hacia 1580 comienza a brillar y a imponerse en el gusto de los lectores. El cariño a Garcilaso nunca menguó, pero los versos de Boscán, de Cetina y de muchos otros han dejado de intere-

${ }^{25} \mathrm{El}$ final del soneto de Góngora es análogo al de "Imagen espantosa de la muerte..." de Lupercio de Argensola: "...y déjale al Amor sus glorias ciertas".

${ }^{26}$ Cf. supra, nota 9. “¿Tengo, si el duro celo está delante, / de cerrar estos ojos...?", se lee en la quinta estancia de la "canción desesperada" de Grisóstomo (Quijote, I, 14) seguramente por razones métricas, pues antes y después de ese verso se lee celos en plural. Rodríguez Marín, ed. de 1947, t. 1, pp. 380-381, cita varios ejemplos de celo en el sentido de 'celos' para refutar a Clemencín, según el cual ese celo "está mal empleado" por Cervantes. Sin embargo, el hecho de que los demás traductores de Sannazaro (salvo el anónimo de la Silva poética, mencionado supra, p. 964) digan celos y no celo indica que ya en el siglo Xvi era válida la observación de Clemencín: que "el nombre celo tiene una significación en singular ['cuidado, solicitud'] y otra en plural". 
sar a fines del siglo Xvi: se les siente fáciles, blandos, flojos, vacíos, desmayados, en comparación de lo que hacen esos jóvenes -Góngora, Lope, Luis Martín, Lupercio de Argensola, Arguijo... - cuyos versos imprimirá Espinosa en 1605. Los sonetos que Góngora comenzó a componer en 1582 son ya otra cosa.

Muy pocos años antes, en 1578, se quejaba Lomas Cantoral de que, "siendo los españoles tales" que se aventajan a las demás naciones en todo cuanto emprenden, "y siendo también la lengua española tan capaz de poesía", la producción poética de España siguiera tan por debajo de la de Italia (y no sólo de Italia: "quien también leyere los franceses, no los verá tan ajenos de las Musas como a los españoles"). No pocas deploraciones como ésta se escucharon en el siglo xvi. Los poetas italianos "acomplejaron" a los españoles durante largos decenios ${ }^{27}$. La deploración de Lomas Cantoral es una de las últimas expresiones de ese "complejo" que muy pronto desaparecerá (o se disimulará por lo menos), y tiene la virtud de completarse con un análisis de las causas del atraso de España. Lo que pasa, según Lomas, es que las naciones extranjeras, y en particular Italia, han cultivado asiduamente la imitación de los poetas griegos y latinos, cosa que España ha descuidado, pues "¿quién hay de nuestros españoles que con verdadera imitación haya seguido las pisadas de aquellos primeros y divinos poetas? Cierto que, si decimos verdad, pocos o ninguno" 28 . Las naciones extranjeras toman tan profundamente en serio la imitatio, que "tienen instituidas públicas academias donde no se profesa otra cosa, y con ella han enriquecido su lengua y adornádola con nuevos números y ritmos'. La imitatio, en efecto, no significa inmovilidad: un buen imitador no puede cerrar

${ }^{27}$ Boscán, que era optimista — sobre todo viendo lo que hacía Garcilasoy preveía para la poesía española un gran futuro (" . . . si los tiempos con sus desasossiegos no lo estorvan, podrá ser que antes de mucho se duelan los italianos de ver lo bueno de su poesía transferido en España"), añadía inmediatamente: "Pero esto aún está lexos, y no es bien que nos fundemos en estas esperanças hasta vellas más çerca".

${ }^{28}$ Exceptúa sólo a Garcilaso, "que, movido de los italianos..., en la parte que imita a los latinos fue excelente y divino" (o sea allí donde imita a Virgilio, Horacio, Ovidio, Ausonio, etc.); y alude a algunos modernos "que esconden sus virtudes del vulgo profano e ignorante" pero que, si se decidieran a salir en letra de molde, levantarían la poesía española a cumbres altísimas. (Se refiere muy probablemente a las traducciones e imitaciones horacianas de fray Luis de León, que tanto tardarían en imprimirse). Las citas del prólogo de Lomas Cantoral proceden de los extractos de Gallardo, t. 3, cois. $402-404$. 
los ojos a "la condición y novedad del tiempo y costumbres, y la diferencia de la lengua". En otras palabras, imitatio e inventio están íntimamente trabadas. Si vemos a los poetas italianos en relación con los latinos, bien "podremos decir que es mayor su novedad e invención que su imitación".

En la teoría de Lomas, que es la de muchos, está implícita la siguiente idea: si los italianos han alcanzado la altura de los griegos y latinos, bien podemos los españoles acortar camino: imitemos a los italianos, pero imitémoslos con rigor, con profesionalismo. A esto dedicó él lo mejor de su tiempo ${ }^{29}$. Y esto es lo que de manera aún más rigurosa y profesional hicieron inmediatamente después de él varios de los mejores poetas de las Flores de Espino$\mathrm{sa}$, ese gran testimonio de la madurez de la poesía española ${ }^{30}$. Los sonetos traducidos del italiano - y no sólo los de Góngora- cuentan entre las más lucidas "flores" del ramillete espinosiano. Exigente seleccionador como se nos retrata en su prólogo, Espinosa tuvo el buen sentido de acoger, al lado de " $\mathrm{O}$ Oh niebla del estado más sereno...."' y las otras treinta y seis composiciones de Góngora, la composición única de ese Jerónimo de Mora cuyo nombre de pila ni siquiera conocía, pero cuya traducción de Sannaza-

${ }^{29}$ Es curioso cómo, después de encarecer el summum bonum de la imitación de latinos y griegos, confiesa Lomas que él no ha seguido ese camino, sino que se ha contentado con imitar en algunas obras a "los castellanos antiguos, y en otras a los italianos modernos". Es la única mención que hace de sus traducciones.

${ }^{30}$ En su brevísimo prólogo "Al lector", aunque pone los productos de "los gentiles espíritus de nuestro tiempo" muy por encima de los versos. de Castillejo y Montemayor ("venerable reliquia de los soldados del tercio viejo"'), Espinosa no se muestra muy seguro de que el público sabrá apreciar la modernidad de las Flores: lo que imprime - dice- es "la muestra del paño: esto es entrar un pie en el agua para ver si está quemando; si os contenta, le daremos al libro un padre compañero", etc. (el "padre compañero", o sea la Segunda parte de las Flores, compilada por Juan Antonio Calderón en 1611, no se imprimió hasta 1896). Consciente, por otra parte, de que la imitatio por excelencia, la prestigiosa, es la de los poetas antiguos, en la portada misma anuncia: "Van escritas diez y ocho Odas de Horacio traduzidas por diferentes y graves autores admirablemente", y al final del prólogo insiste en su llamado de atención: "De passo advertid que las Odas de Horacio son tan felices, que se aventajan a sí mismas en su lengua latina". De las imitaciones de los italianos, que son mucho más de dieciocho, y entre las cuales hay verdaderas joyas (de Góngora, desde luego, y de Luis Martín de la Plaza, Barahona de Soto, etc.), no dice Espinosa ni media palabra. Hubiera tenido que elogiarse a sí mismo, pues en las Flores incluye su traducción de Bernardo Tasso, "Estas purpúreas rosas que a la Aurora...", que es muy bonita. 
ro satisfacía evidentemente sus exigencias de bondad y de modernidad.

Además, no había peligro de duplicación. El soneto "Celos, de quien bien ama amargo freno... " es muy distinto del de Góngora. Si ponemos el uno al lado del otro -Espinosa los imprimió en lugares separados -, inmediatamente se agita ese mar de tinta formado por cuanto se ha dicho sobre el tema traduttore-traditore, o sea sobre teoría y crítica de la traducción: fidelidad, literalidad, traducción libre, paráfrasis, imitación, reelaboración, segunda creación... ${ }^{31}$ Las traducciones de Mora y de Góngora representan soluciones diametralmente opuestas. Si la "traducción ideal" es la que más se ciñe a la letra, entonces el soneto de Góngora, que es de principio a fin una sarta de infidelidades, queda muy por debajo de la de Mora. Pero si la "traducción ideal" es la más digna de leerse, la más bella, entonces la superioridad del soneto de Góngora es indiscutible. Recordando la observación de Lomas Cantoral sobre "la diferencia de la lengua" y los cambios "del tiempo y costumbres" ( = cultura), diremos que Góngora fue normalmente consciente de lo primero y agudamente consciente de lo segundo. Él vino al mundo en 1561, y Sannazaro en 1458. Un siglo los separa, ¡y qué siglo! No sólo los lectores italianos, sino también, en número cada vez mayor, los españoles, han presenciado la elevación del lenguaje poético petrarquista por obra de un Ariosto, un Tansillo, un Ciego de Adria, dos Tassos y tantos otros. Sannazaro ha ido quedándose atrás. Y sin embargo su soneto "O gelosia...!" perdura en la memoria y el cariño de todos. Jugando gongorinamente con el verbo traducir, diríamos que Góngora traduce por partida doble el soneto de Sannazaro: lo pone en español y lo 'traslada' a 1582: lo echa a vivir en una cultura no sólo nueva, sino completamente española. Lo coloca a la altu-

31 J. P. WiCKERShaM CRAWFORd, "Italian sources of Góngora's poetry", $R R, 20$ (1929), 121-130 - a juzgar por las notas de FuciLla, Estudios, pp. 252254-, acepta en general las indicaciones de Salcedo Coronel en cuanto a las "fuentes italianas" de Góngora (salta a la vista, por ejemplo, que " ¿Cuál del Ganges marfil o cuál de Paro...?" deriva de "Qual avorio di Gange o qual di Paro... ?" de Ariosto); pero en varios casos las pone en duda y aun las rechaza, porque Góngora se ha apartado de la fuente más de lo "lícito"' (así el bellísimo "Varia imaginación que en mil intentos. .. " en relación con "Pensier che mentre di formarmi tenti..." de Torquato Tasso). De " $i \mathrm{Oh}$ niebla del estado más sereno... !" dice Crawford que es "imitación indirecta" (?) de "O gelosia...." (En el manuscrito de Barcelona, según Millé, nota al núm. 227, el soneto lleva este epígrafe: "A los celos. Alude a un soneto de Sannazaro"). 
ra de los tiempos. También Bernardo Tasso y Tansillo habían reescrito el famoso soneto. Pero la reescritura de Góngora da indicios de una verdadera translatio imperii: en 1582 era él, y no un italiano, el mejor intérprete de Sannazaro.

Por supuesto, el "tema" de los celos es universal, y muchas de sus expresiones poéticas españolas no tienen relación con " $\mathrm{O}$ gelosia...!"32 En sonetos como "Celos bastardos, mal nacidos celos..." o "Celos, que amor en las sospechas cría...", Lope de Vega parece tomar adrede otro camino ${ }^{33}$. Pero cuando Juan de la Gueva escribe el soneto que comienza "Dan mil filo-poetas en cansarse / en hacer invectivas de los celos...", alude evidentemente a las traducciones e imitaciones de "O gelosia . . .!", como se ve por lo que dice en el primer terceto:

Unos les llaman furia, otros infierno, otros rabia, otros peste, otros vestiglo, dando de sus efectos la memoria... ${ }^{34}$

Góngora tenía en la cabeza el viejo soneto (o su propia versión de él) al escribir los primeros renglones de Las firmezas de Isabela (soliloquio de Marcelo):

¿De qué seno infernal, oh pensamiento, o por dónde has venido, si de tus alas torpes huye el viento?...

${ }^{32}$ Bastante celebrado en el siglo XVI fue el soneto dialogístico "-¿Qué cosa son los celos? - Mal rabioso. / — ¿De qué nacen o vienen? - De temores...", pues se encuentra por lo menos en estos tres mss.: Cod. Reg. Lat. 1635 de la Bibl. Vaticana, fol. 40 (cf. H. G. JonEs, $N R F H, 21,1972$, p. 386); B.N.M., ms. 4117, fol. 89r; y Flores de baria poesía, ed. cit., p. 464 (atribuido aquí al Licenciado Dueñas). También está en estas Flores el soneto de Cetina "Cruel y uenturosa geluzía. ." (cf. supra, nota 9).

${ }^{33}$ Sobre el primero de estos sonetos, que alguien atribuyó erróneamente a Cervantes - quizá porque Cervantes se interesó tan en serio en el problema de los celos (cf. Marcel Bataillon, Erasmo y España, $2^{\text {a }}$ ed., F.C.E., México, 1966, p. 783)-, véase M. C[ARDENAL] en $R F E, 25$ (1941), 400-403, y R. Osuna en RLit, 30 (1966), 75-76. El otro soneto puede verse en las Poesías líricas de Lope, ed. Montesinos, Clás. cast., t. 1 (ed. de 1968), pp. 188-189.

${ }^{34}$ Gallardo, Ensayo, t. 2, col. 681. Este curioso "soneto de los sonetos a los celos" termina con un tour inesperado: ". . . mas yo, que ardo en un desdén eterno, / si me celara la que honora el siglo, / bien y descanso los llamara y gloria”' (o sea: 'iqué diera yo por que la bella ingrata tuviera celos de mí!'). 
Los ecos sannazarianos son perceptibles en las octavas que recita Clarenio en la novela pastoril de Bernardo de Balbuena:

Zelos, rabia bebida por los ojos, venenos que emponzoñan alma y vida...

Sois venenosas víboras. . .

Verdugos de amorosos pensamientos, rescoldo en medio el corazón sembrado, ¿de qué infierno sacáis estos tormentos que sin llamas me dejan abrasado?... ${ }^{35}$

y también en el soneto de Soto de Rojas "A la Invidia":

Hija mordaz de infames coraçones, que hazes, qual áspid, de la flor veneno...

Muerte del mundo, que muriendo creces, imagen de las penas infernales... ${ }^{36}$

Debe haber en la literatura del siglo XVII muchos otros ecos que se me escapan. Quizá el título mismo de $E l$ mayor monstruo del mundo hiciera pensar al público de Calderón en el soneto de Sannazaro. El último eco que conozco es un soneto escrito ya en tiempos de Carlos II:

Zelos, que al alma sois tan inmortales...

Víuoras que entre flores y cristales

la ponçoña guardáis.

¿De quál patria venisteis tan violentos

a embaraçar las glorias de vna vida... ? ${ }^{37}$

Antonio Alator re

El Colegio de México

${ }^{35}$ Siglo de oro en las selvas de Erifile, Ibarra, Madrid, 1821, al comienzo de la Égloga IX.

${ }^{36}$ Pedro Soto de Rojas, Desengaño de amor en rimas, Madrid, 1623, fol. 141v. (En los preliminares del libro dice Lope de Vega que el autor "avrá doze años que juntó estas Rimas", pero se habfa resistido a publicarlas. De hecho, la "suma del privilegio" es de 1614).

${ }^{37}$ Joseph Delitala y Castelví, Cima del monte Parnaso español, con las tres Musas castellanas Caliope, Vrania y Euterpe, Cáller, 1672, p. 137. 